\title{
PRISON ABOLITION
}

\author{
Yves Bourque
}

\section{Introduction}

From the prehistoric lad stealing his cave mates' chunk of raw brontosaurus meat and running away wildly to the forest with it, to the twenty year old holding up a bank teller and fleeing with eight hundred dollars on top of his motorcycle, what we call "crime" has remained much the same. What has changed are the names, social importance, and most particularly our ways of dealing with the perpetrator of "wrongful acts". Doing something wrong, against basic moral principles, against the rules, the laws, against our neighbour, is such an intrinsic quality, something so inherent to human beings, that no one is truly shielded against the shame of being reprimanded by his or her parents or against the ignominy of being judged and condemned by a "Court of Law". Those who during the course of their adult life do not find themselves in such circumstances are called "righteous", "honest and law abiding citizens;" the others, "criminals" to their death.

In Canada, this last group is growing in alarming proportions since more than one out of every thousand is in prison on any given day. Unmentioned are the countless others under the all-powerful domination of the $\mathrm{Na}$ tional Parole Board or on probation; and uncounted are the tens of thousands who will never again be "free" because of their experience in Canadian prisons: the psychological, social, and economic weight of their "criminal 
record". Prisons, no matter how "beautiful" we make them, no matter how "humane" we would have them, no matter how "rehabilitative" we devise them, will always be horror houses where public vengeance is administered, cruelly and destructively, on persons who are the most vulnerable and defenseless of our society. In the light of logic, common sense and, indeed, humanity, prisons are absolutely unjustifiable, intolerable, and immoral. Building prisons, vindicating and supporting them, working for them, and thriving from them are crimes against humanity.

I am in favour of prison abolition as one who is in favour that the sun should rise on the morrow. Society will continue to destroy itself if the present general ideology about our criminal "justice" and prison system is allowed to remain.

I am from a lower middle-class, French Canadian family of Montreal. Early, I was caught up in the music/ drug subculture of the "hippie" movement of the late 1960 's. At age thirteen I smoked my first marijuana cigarette and at sixteen I was already considered a dare-devil when it came to drug experimentation, taking L.S.D., mescaline and injecting methamphetamine. Eventually, I dropped out of school and, as was the custom, went hitchhiking across Canada, ending up in Vancouver's hippie haven, Gastown. On July 12, 1975, at age nineteen, I robbed forty dollars from a parking lot attendant and a few minutes later was arrested by the Vancouver City Police. When I arrived at the police station I was taken upstairs into a small room by two policemen, told to undress, and for fifteen minutes underwent a forced questioning while I stood there without a stitch of clothes on, outrageously humiliated, afraid and shivering. I was found guilty of robbery and sentenced to nine month's imprisonment. My girlfriend was one month pregnant.

I was sent to Oakala prison (in British Columbia) where for three weeks I experienced terror, indignation, and degradation. Sometime later, I was relieved to be transferred to a prison camp called Stove Lake, near Mission, British Columbia. There, I was made to work ten hours a 
day, and Saturday mornings, for the benefit of British Columbia's Provincial Parks and the Ministry of Forestries. I made 35 cents per day and as I took on responsibilities, worked my way up to the maximum pay of $\$ 1.25$ per day.

The summer had been very hot and dry. A forest fire broke out, and the forty-five or so prisoners were told they would be given seven dollars per hour to help extinguish the blaze. I volunteered, as did all the others. Equipped with spray cans carried on our backs, water pumps, shovels and rakes, we fought the flames for three days, working to the point of exhaustion. I still remember vividly my friend G.P. being flattened to the ground by a water bomb dropped by a huge, low-flying, fire-fighting aircraft. After the inferno, a security rule called for a watch of seven days and nights over the site. Imagining how the money I was making would help my pregnant girl-friend to cope better, I volunteered and spent the best part of the following week in the charred wilderness under pouring rain.

Revolt set in when we all learned that we would not get the promised money but instead the usual 35 cents a day. I was furious and I organised a sit-down strike to protest; all but a few followed me. That morning we were all jammed into trucks and returned to the Lower Mainland Regional Correction Centre. Upon arrival, we were put in metal cages aligned endlessly against the wall of West Gate "A", and one after the other, we were taken out, walked by three guards in front of all the caged men and forced to disrobe, to bend over and to spread the cheeks of our ass in full view of everyone. I remember a middle-aged Hungarian who didn't understand the English commands very well and who stayed a good five minutes bent over in front of us, lifting his feet, spreading his arms, until the three irate guards let him go back to his cell, without spreading his cheeks. G.P. told me the man was crying on his way back to his cage. For the first time, prison reality struck me. I was in danger, and no matter what happened there would be nobody to help me.*

*For a month, every morning, one after the other, we paraded from our cage to a single toilet at the end of the tier to empty the nylon bucket we had to defecate in. 
I was subsequently returned to the prison camp where I resumed my work. One afternoon, in early November, as I was slashing and burning in preparation for a forestry road that would be laid, the guard nearest to me received a radio message and straight away came to advise me that $I$ had been granted National Parole. All I remember is throwing my hard hat in the air and running the two miles back to the campsite where I waited with agitation to be taken out of the forest to Haney Correctional Centre from where I would be officially released. Minutes seemed like hours, thinking of how I would surprise my girl-friend. Perhaps I would use the back door and appear, unsuspected, with the greatest hug and kiss she had ever had; or perhaps it would be better to phone first when I got in town in order not to cause her to miscarry or something.

I never thought we were so deep in the woods and the road to Haney seemed interminable. Once there, I had to wait some more - anxious, happy, and moist-handed. Finally, they gave me my wrinkled up civilian clothes, my wallet, from which I took a nostalgic look at a photo I.D. card on which I sported my once cherished very long hair. I finished tying my shoes, signed some forms, and headed for the door with a bus ticket to Vancouver in my hands. I didn't have a foot across the doorway when a rubicund faced guard yelled my name: "Bourque!" I turned around and with one look at the guard's faces an awful feeling overcame me. I turned white. They said: "A telex just came in. Your parole is revoked, you might have an outstanding charge in Montreal...."

I was back in the prison camp for supper but didn't eat, instead, shattered, I went to the tool shed and made myself a knife, not knowing exactly why. The rest of that sentence, which I ended up doing completely, turned out to be just a continuum of abuses and humiliations which saw me locked-up an additional thirty days in the "hole", and placed in a wilderness prison called Mini-Max.

I was released at the end of February 1976. It was raining and cold, and whatever elation I might have felt was negated by bitterness. My son had been born and adopted, 
my girl-friend had slashed her wrists in an attempted suicide, and she was being cared for by a couple of sympathetic social workers.

Six months later, I was charged with "trafficking narcotics". I had directed an undercover agent posing as a hippie, to a friend who sold him $\$ 10.00$ worth of marijuana. I received the equivalent of a two and a half year sentence after having spent eight months in remand, in Oakala's South Wing.

I will be thirty-two next May, and so far I have spent the best part of my life in twenty-two prisons and penitentiaries across the country.

Recently, while serving a nine year sentence in Archambault Penitentiary, Ste. Anne des Plaines, Quebec, I could no longer suffer the totally oppressive context and humiliation imposed on us by female guards working in our living quarters so I started to categorically refuse to have my bottom and crotch palpated daily by female employees. Soon, one of them laid a formal charge on me and had me brought to a disciplinary tribunal. The judge sentenced me to five days in the "hole" for refusing to be searched by her. After being taken to the punitive dissociation area for some of the longest and most painful minutes in my life, I was forced by three employees to undergo a nude search in the presence of the female guard who had me condemned. I refused! They threatened violence. I was screaming in my soul, holding back the tears of fear and shame while they were pressing me to disrobe. I yelled that they didn't have the right to do that; that it was illegal! They told me they would "rip the clothes off my back." I became almost hysterical. Finally, she moved from the doorway. I took my clothes off. They made me turn around, bend over, spread the cheeks of my ass, shake my hair, take my partial plate out, and with a grin on his face, the officer in charge told me to get dressed. The metal door slammed! ... I wanted to be dead. A wave of morbidity overcame me in my cement cubicle, and I gave in to it.

Fearing repercussions, my neighbour would not testify so I could not lay criminal charges of mental cruelty 
against the guards. So I simply stopped eating altogether. My five days in the "hole" expired, but I refused to come out. After nineteen days of a hunger strike I was taken by force to Donnacona Penitentiary, near Quebec City, where I was put in "administrative segregation" (i.e. twenty-three hours a day in a cell) because of my protest. That was four months ago, and although I started to eat again after twentyone days, I am still locked-up in my "concrete uterus", without any privileges, pending a transfer out west.*

\section{Prison: "From Outside"}

Driving along with my family, as a kid, I remember my father pointing out the Old Penitentiary in Laval, and I remember also how abstract a concept it was to imagine the "bad men" who, he was explaining, were locked-up in there. In the course of all these years in prison, and from observing and talking to many a "citizen", including my own family, I have come to realize more clearly the extent to which conceptual distortions have been conveyed when it comes to prison, prisoners, and even crime.

There are reasons for these gross misconceptions. In order to justify the extravagant sums required to breath life in an insatiable monster such as the Canadian Correctional Service, one must give it a character of necessity and, indeed, urgency. This is mainly achieved by the media's over zealousness in exacerbating public emotions, anger, and fear; they are very successful at telling only one side of the story. This has provoked the injustices and inhumanities of our criminal "justice" system. In the context of the Canadian Society, the six o'clock news will report a most regrettable and dramatic incident like so:

Today, a young bank teller was shot in cold blood in the course of a robbery. When apprehended by the police, it was found that twenty-six year old so and so had just recently been released on

\footnotetext{
*Subsequently, I addressed a twenty-eight page letter to the Prime Minister of Canada describing some of the horrors, abuses, and degradations that go on daily in prisons across Canada.
} 
parole after having served only four of a seven year sentence for robbery. More news later, now, these messages of interest.

\section{It does not say:}

Yesterday, again, a young bank teller was shot in the course of a robbery at the corner of such and such a street. A humanitarian organisation that is now helping the parents of the victim cope with their immense grief and anger has told this media that the apprehended twenty-six year old had, since age seventeen, undergone six years of "legal" physical and psychological torture, degradation and systematic dehumanization at the hands of the penal authorities. Socially and emotionally assassinated so and so had once told the institutional psychiatrist that the scars of cigarette burns on his penis, inflicted by police in a forced questioning pertaining to the denunciation of a major heroin dealer, had caused him to try to commit suicide at least three times while in prison and once at his mother's house.

More news later, now, this report on the devastating effects of the cruise missile.

I am not trying to minimize the human tragedy that any wrongful act presents, but the creation of a "public enemy" that we must subdue at all cost, as quickly and as decisively as possible, proceeds from the domain of the absurd, and although the vast majority of Canadians endorse the concept with great facility, not to say eagerness, it is nonetheless devoid of any logic and honesty. It is at the base of many social dissensions caused by fear, anger, hatred, and ignorance.

Everyone, every single human being, is a potential "criminal", and in this country, anyone can be switched from the camp of the "free and righteous" to the camp of the "undesirable enemy," quite irreversibly, given the state of our prison system and criminal law. Nevertheless, most

prisoners and ex-prisoners come from the "lower" strata of society: they are the poor, the undereducated, the socially 
(thus politically) disadvantaged, and the contemptible in the light of everyone. Many others come from broken families, alcoholic parents, disadvantaged minorities and have experienced intense socio-psychological backgrounds (e.g. homosexuals and transvestites who found themselves in rejecting contexts). Strangely (not a bit), prison guards and many employees are issued of that same fundamental stock, as are the police. So, on one side you have the incarcerated, oppressed, terrorized poor and disadvantaged; and on the other side the not-so-poor-and-not-so-disadvantagedanymore incarcerator, oppressor, and terrorizer that takes care of them. The rest of the poor, the plain, the unadorned and "ordinary people," are neither predator nor prey, yet they are nonetheless part of that same general "group" which is most influenced by the diverse media, sensationalism, and trends; and most easily shifted to and fro and whipped-up against crime and criminals to the point of supporting and advocating the torture, degradation, and destruction of countless human beings, of their own class. And that takes care of them.

Sensational crimes and murders make best-sellers, and they represent a lucrative business. The mass media has commercial interests to look after, and political interests as well. People eat crime up like candies. Television and movies are riddled with it. Crime, punishment, vengeance are powerful trends and it would be hard for the media to "kick against the pricks". Moreover, it is made to look like our democratically elected government knows what it is doing when it comes to "law and order", police, and prisons. They build prisons, more and more of them, they devise systems, and construct new rules. They hire tens of thousands of persons to whom they give certain powers, uniforms, weapons, salaries, security, social status, and acceptance, all contributing factors to the strengthening of the legitimization of torture and degradation. Prison guards and employees, citizens, even many prisoners are so engrossed in the induced illusion of a necessity for prison, so completely taken by the hocus-pocus that strives to make them look "not too bad after all", that they scorn 
the very concept of prison abolition. It requires a considerable amount of effort, from anyone's part, to live in a lie as solidly implanted and as cleverly disguised as the "free and civilized Canadian society" and not be blinded be the glare.

It all amounts to a systematic desensitization of the "general public" and particularly of prison personnel, to whom any torture, degradation, violence, and oppression becomes not only legitimate but natural. In fact, when a prisoner shows signs of "rehabilitation" to the penal authorities or parole board, these signs are usually indicative of a complete engrossment in the "system;" an acceptance of her/his outrageous sentence, acceptance of all the injustices, tortures and degradations that $\mathrm{s} /$ he has been subjected to upon arrest, during the legal procedures and especially while incarcerated. A complete submission to fascism. Any prison employee becomes a mercenary because he or $\mathrm{s} / \mathrm{he}$ has to comply with certain directions in order to get her/his recompense. And not withstanding their own obvious propensity for sadism, they must undertake certain actions and display attitudes that are all meant to debase, oppress, and subdue the prisoners. They are taught certain "facts" by the prison makers which automatically justifies their being "right" and the prisoners being "wrong"; these beliefs, issued of brainwashing sessions, criminological theories, media, and force of habit, are being strengthened daily by the attitude and behaviour that every inmate will display from time to time under the pain of torture, fear, and humiliation.

Prison, and what prisoners actually undergo inside of them, is a major factor in causing crime. Nevertheless, this fact does not pose a threat to the ruling class the prison serves most. On the contrary, "mutants", vomited back to their alma mater (minus the family link) are much more liable to rob and/or kill a corner store owner than to commit a deliberate terrorist act aimed directly against those who have warranted their torture and debasement.

Today, even kids are taught to embrace the concept of punishment. Routinely, college and university students of criminology classes and others are paraded through 
brightly painted "institutions", shown pleasant looking cafeterias, sports equipment, houses for family visits, landscaped grounds, and get to meet "selected inmates" and members of the staff in "controlled" situations and settings where the ignominious and revolting fact that they are amidst a human zoo becomes undiscerned in the gay, but diffident chit-chat.

\section{Prison: "From the inside"}

While the degradation and alienation is indubitable, and beyond the "off-hand" deprivation such as the loss of liberty, security, privacy, autonomy, gratifying sexual relations, freedom of speech and association (and one must bare in mind that these are but the foundations in which every prisoner is set), countless daily abuses and illegalities administered by individuals with nearly unlimited, justified power over prisoners, are more or less endured by a recourseless inmate population. Any safeguard to protect Canadian prisoners from abuses and psychological tortures is absolutely futile since any Law, Rule, Directive, or Standing Order can be and are broken by invoking the preservation of the "Good Order of the Institution" and/or by any employee that wants to "take it out" on the inmates since it is common knowledge, and fact, that inmates have no means of defending themselves and that they do not pose any serious legal threat to prison staff. On the other hand, at the first threat of physical retaliation, the inmate is quickly and vehemently subjected to restraint and legal violence.

The "improvements" brought to the living conditions of Canadian prison in the past decades, even education, have all been efforts directed toward a more complete justification of the "system" in the public eye, for obvious political reasons, rather than an actual bettering of the system (if that is at all possible!). Some modern prisons, with "comfortable" cells, better meals, plants in hallways, the possibility of buying one's own television, radio, or trade programs have not taken away any of the violence, humiliations, fear and alienation inherent to Canadian jail houses. Quite the opposite, they have engulfed the more undiscer- 
cerning prisoners in an added state of confusion where their hurts and pains are less readily associated with their immediate environment, leading to unsurpassed senses of guilt and self-hatred. Moreover, all these subterfuges have added to the boldness and self-justification of employees to a point where even institutional psychologists (absolutely unprepared to work in prison) find inmates' outrage to be just another indication of prisoners' "immaturity" and "criminal nature", thus adding a "pathological" stigma to an already degraded and immensely hurt person.

The implementation of "family visits privileges" where an inmate may be allowed up to seventy-two hours of privacy with wife and/or family, in a house or mobile home especially devised for that purpose on the prison grounds - has proven itself to be the utmost tool of degradation, humiliation, and manipulation; sexual gratification is now being offered as a reward for compliance and submission! An inmate that did not have six months or more "recognized relationship" with a woman prior to his arrest will most likely spend the next five, ten, or fifteen years settling for stories and masturbation. Moreover, those who are "eligible" for such programs find themselves in a position where they feel they are begging to be permitted to have sex with their wife or girl-friend to a classification officer who is often a young woman, or to a special board formed of half a dozen prison officials who will bring-up past "offenses" and long forgotten "disciplinary court" dealings in order to aggravate and "test" the inmate who will bite his tongue and swallow as much double-talk and indignation as he can in order to be able to caress breasts he has only imagined for many months. Not withstanding the short moments he may get to spend with his loved ones a couple of times a year, and depending on the acuteness of his moral discernment, the inmate will invariably feel some sense of disgust and self-betrayal for not having expressed his true sentiments and for having let himself be disgustingly manipulated and degraded in order to be able to fulfill one of his strongest physical and emotional needs.

The same machination takes place when a prisoner is 
in front of the "parole board," where individuals who have "carte-blanche" control over her/his life make decisions and probe the inmate from files and reports written about her/him, all kinds of reports written by employees over the years that the inmate knows nothing about and that $\mathrm{s} / \mathrm{he}$ is not allowed to see, whether or not $\mathrm{s} / \mathrm{he}$ applies under the "Privacy Act". Some of these reports are written by psychologists after new and unaccustomed prisoners have been duped into seeing them, not knowing that everything that transpires from the conversations, even the most intimate details, becomes public, available to all except to her/himself.

With the accepted belief that any torture imposed on a prisoner is justifiable by the "fact" that he's a criminal and an undesirable entity of the human race, the Canadian government has fully integrated the living quarters of male inmates with female guards and employees - pushing to new heights the humiliation, degradation, and torture of these men. Already, hundreds of inmates have been forced to undergo illegal nude searches in the presence of female employees and many that have refused have seen their clothes taken off their backs by force in the presence of young women they have to live with for years. The few that have managed to get the guards prosecuted in Federal Court have seen them get not much more than a reprimand; meanwhile these practices continue everywhere, particularly in medium security institutions. In many prisons, male inmates are forced to undergo medical interviews and examinations in the presence of female guards, while female prisoners are specifically protected against the very presence of male staff in their living quarters. In male prisons, suicidal inmates are thrown naked in bare cells, without any clothes or blankets to cover themselves, with only a hole in the middle of the floor to defecate in, while they are being watched by women guards on a closedcircuit television screen and through the window of the cell door; moreover, ordinary inmates are often thrown naked in these cells as a means of punishment for offenses involving the guards directly. Sexually deprived inmates are 
forced to have their body completely frisked, daily, by female employees; they are looked at in their cells by the same, whether they are defecating, masturbating, or washing themselves. In many prisons, male inmates are forced to shower in full view of female employees, more so in punitive dissociation areas and in penitentiaries considered more humane and of lesser security. Many live with the daily fear of being violently humiliated.

This cross gender guarding of male prisoners has given rise to an excruciating impulse of violence against women and to "rape oriented" patterns of thinking. It has given rise to mutations in inmates' sexual and psycho-sexual behaviors, to countless cases of exhibitionism and voyeurism because a human mind has a tendency to transform into "pleasure" pains and hurts that are unquenchable. Countless frustrations and humiliations of a sexual nature are added on the already unbearable yoke that inmate must endure, specifically because of the presence of women guards.

\section{Abolition}

If we are to think of abolition in any serious way, and if we are to devise "humane" ways of dealing with the phenomenon we call crime, we must have the courage to face some sobering facts. An incalculable number of Canadian citizens have forever lost their human wholeness and social integrity because of their condemnation to prison. And countless others are being systematically degraded and rendered insane by the same means. There is no place for them in this society, as it is, because it has been conceived for other kinds of beings, not "mutants"; these people have not much left to lose, and many have come to realize this fact. Moreover, they are jam-packed and supercharged with so much hatred and pain that a scream as big as the whole universe would not relieve them of it. More than ever, they will continue to steal, rob, rape, and kill, with, in their soul and mind, all the justification in the whole world needed to do so; they will grab all they can, while they can, because soon they will either commit suicide, be killed by the po- 
lice, or brought back to prison - the latter being an indispensable and deliberate contrivance on the part of the "authorities" to perpetuate and expand a system that is outrageously immoral and inhumane. If we are to gradually abolish prison, how will we care for these people whose sense of security and freedom is forever lost with the acquired knowledge that anything can be done to them, anywhere, at any moment and for any reason? What will we do with the tens of thousands of socially, psychologically, and emotionally mutilated ex-prisoners when warehouses are no longer there to store them? Can we possibly re-integrate those who have been systematically alienated from society and humanity?

How about the tens of thousands of prison employees, guards and jailers? Can we help them readjust when it is common knowledge that they are as "bad", if not worse, than the "criminals"? What will their "careers" and lives amount to? Will they ever be able to face the music? How will Canadians cope with our image of ourselves as a nation of civilized people?

Prisons are not being "bettered", they are being "worsened". With the most dangerous belief that we are "improving" our prison system and lessening the trauma caused to prisoners, we are headed for an increasingly steeper precipice and we are giving prison officials, employees, and guards more leeway and justification to go on degrading and abusing human beings, to the detriment of all Canadian citizens and, indeed, humanity.

How will we go about implementing whatever solutions abolitionists are proposing? I suggest this: First, we must at all cost begin a systematic denunciation of the Canadian prison; we must by all means expose the futility and cruelty of it along with the lies and hypocrisy that are at the base of our criminal and penal system. We must at once begin serious and unbiased empirical studies on the social and psychological effects of incarceration in Canada and we must immediately find ways of stopping the psychological atrocities, tortures, abuses, and illegalities that prisoners are subjected to daily. 
Second, we must at all cost "de-Hollywoodize" and "depoliticize" crime and gradually transfer the "responsibility" where it belongs, in the social arena; we must start to contemplate and accept the fact that we are all guilty and that by putting all the blame on one person and destroying that same person we are going against the most fundamental rules of logic: we are destroying ourselves.

Third, we must be honest and take courage, and face the inescapable truth that social dissensions, crimes, prisons, and such are nothing but a physical manifestation of a metaphysical reality, i.e., the prevailing and innermost feelings and thoughts in the heart of us all. What we observe, everywhere and anywhere in this country, on the political and social landscape, is $u s$; we must change $u s$, if we long to see real changes appear and stay.

\section{Afterward}

Some years ago I became an artist, a painter; and one night, as I often did, I was laying on my bed, in my cell, sounding my mind and soul for inspiration. Suddenly, in the stillness of the dark, an image came to me that sent shivers through my body: I saw an endless and beautiful landscape, green grass, flowers and trees, and a radiant sunshine flooding it all; and everywhere, like pebbles on a lawn, on top of hills and in valleys, beside the streams and on mountain flanks were prisons, thousands of large, red-bricked buildings with bars in the windows. And as far as the eye could look there was no one to be seen. I never painted that, but the image is as vivid today as it was then. 
